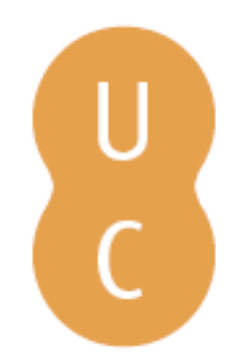

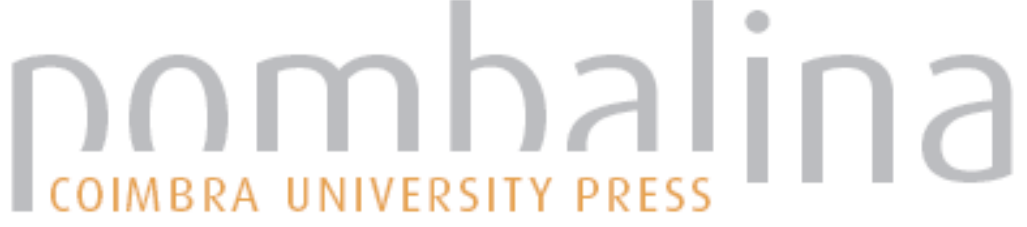

\section{A wearable system for firefighters smoke exposure monitoring}
Autor(es):
Azevedo, P.; Marques, F.; Fernandes, J.M.; Amorim, J.H.; Valente, J.; Miranda, A.I.; Borrego, C.; Cunha, J.P.S.

Publicado por: Imprensa da Universidade de Coimbra

URL persistente:

URI:http://hdl.handle.net/10316.2/34317

DOI:

DOI:http://dx.doi.org/10.14195/978-989-26-0884-6_144

Accessed : $\quad$ 26-Apr-2023 12:14:29

A navegação consulta e descarregamento dos títulos inseridos nas Bibliotecas Digitais UC Digitalis, UC Pombalina e UC Impactum, pressupõem a aceitação plena e sem reservas dos Termos e Condições de Uso destas Bibliotecas Digitais, disponíveis em https://digitalis.uc.pt/pt-pt/termos.

Conforme exposto nos referidos Termos e Condições de Uso, o descarregamento de títulos de acesso restrito requer uma licença válida de autorização devendo o utilizador aceder ao(s) documento(s) a partir de um endereço de IP da instituição detentora da supramencionada licença.

Ao utilizador é apenas permitido o descarregamento para uso pessoal, pelo que o emprego do(s) título(s) descarregado(s) para outro fim, designadamente comercial, carece de autorização do respetivo autor ou editor da obra.

Na medida em que todas as obras da UC Digitalis se encontram protegidas pelo Código do Direito de Autor e Direitos Conexos e demais legislação aplicável, toda a cópia, parcial ou total, deste documento, nos casos em que é legalmente admitida, deverá conter ou fazer-se acompanhar por este aviso.

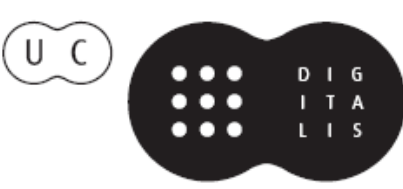




\section{ADVANCES IN}

Forest Fire

\section{RESEARCH}

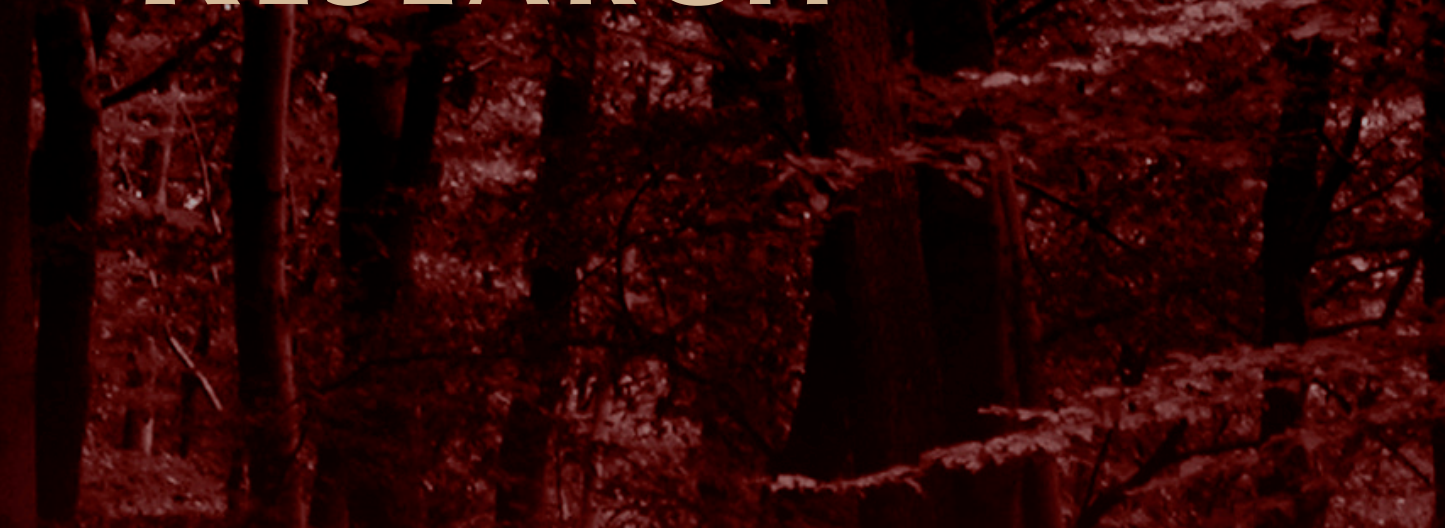

\section{DOMINGOS XAVIER VIEGAS}

\section{EDITOR}




\title{
A wearable system for firefighters smoke exposure monitoring
}

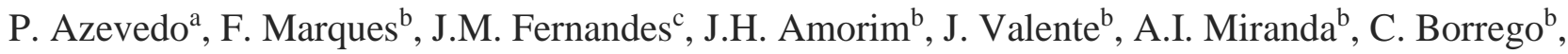 \\ J.P.S. Cunha ${ }^{\mathrm{a}, \mathrm{c}}$ \\ ${ }^{a}$ INESC-TEC/Faculty of Engineering, University of Porto, Portugal.paulo.r.azevedo@inescporto.pt, \\ jpcunha@fe.up.pt \\ ${ }^{b}$ CESAM \& Department of Environment and Planning, University of Aveiro, 3810-193 Aveiro, \\ Portugal,fabiomauricio@ua.pt, amorim@ua.pt, joanavalente@ua.pt, miranda@ua.pt, \\ cborrego@ua.pt \\ ${ }^{c}$ IEETA/Department of Electronics, Telecommunications and Informatics, University of Aveiro, \\ 3810-193 Aveiro, Portugal, ifernan@ua.pt
}

\begin{abstract}
Firefighters (FF) have to deal in their routine with dangerous situations, exposing themselves to extreme environmental conditions, which can put their lives at risk. Extreme heat exposure, smoke inhalation and reduced visibility are among the most significant hazards to firefighters involved in the suppression of forest fires. In this sense, some new technologies were built addressing the monitoring of firefighters health in the field, mainly sport-oriented solutions adapted for both scientific studies and commercial solutions. However, none of those aim at the mitigation of the main reason for incidents involving firefighters: the exposure to dangerous concentrations of air pollutants.

Our purpose is the development of an integrated hardware and software solution that allows the online monitoring of vital and environmental parameters, helping the FF to preserve their personal health and safety. The system is composed of a specific hardware device attached to the helmet that measures several parameters of interest (e.g. elevation, air temperature, atmospheric pressure, luminosity, exposure to carbon monoxide and nitrogen dioxide), and a mobile application running in a smartphone, which processes information gathered by the helmet hardware to determine if the firefighter is at an acceptable level of exposure/danger and triggers an alarm, if necessary.

From an operational point of view, this work proposes a cost-effective solution to monitor FF smoke exposure in typical adverse scenarios such as forest fires, allowing the detection and mitigation of hypothetical intoxication incidents. The hardware component is easily integrated in standard firefighter's protection equipment and the mobile application can run in any "off-the-shelf" mobile computing device. Beyond the stand-alone firefighters monitoring perspective, this wearable technological solution opens several opportunities as a data source. In this sense, under development is the integration of the near real-time observations into a Decision Support System (DSS) aiming to provide knowledge-based aid to firefighters at critical decision-making situations, thus helping with the safe and successful management of fire fighting.
\end{abstract}

Keywords: fire safety; smoke exposure; wearable sensor.

\section{Introduction}

Firefighters (FF) have to deal, in their quotidian, with dangerous situations, exposing themselves to extreme environmental conditions, which put their lives at high risk. Extreme heat exposure, smoke inhalation and reduced visibility are among the most significant hazards to firefighters involved in the suppression of forest fires.

In this sense, there are some new technologies that enable the monitoring of some FF health parameters (e.g. heart rate, ventilation frequency, r-r interval) for commercial [Zephyr Technology, 2014] and scientific purposes [Heimburg et al., 2006]. However, these technologies are only partial solutions and mostly oriented to the offline analysis of physiological data, not taking into consideration the problem 
of aiding the FF in the terrain nor the needed environmental data. Even the commercial solutions are actually adaptations of sport-oriented systems, and are not well suited for realistic operational conditions [Teie, 2005], letting important issues as ergonomic, needed monitoring variables or operational concerns out of their scope.

An illustrative example is the synergy between wearable technologies and mobile computing [Coimbra et al., 2012], in which FF were monitored by their own smartphone [Colunas et al., 2011] and using wearable sensors [Cunha et al., 2010, Cunha, 2012] (see Figure 1). In this previous work, physiological variables were nicely adapted to a wearable system that was specifically developed to FF requirements. Nevertheless, the needed environmental variables were not integrated.
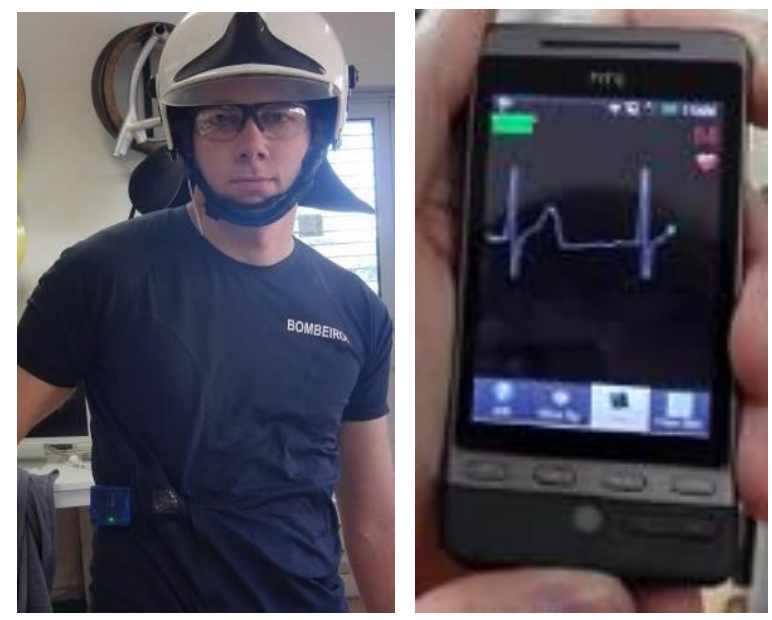

Figure 1. Vital Responder setup: wearable hardware (on the left) and the mobile application (on the right).

Recognising the power of mobile computing devices features (e.g. computational power, wireless networks) using wearable hardware as terrain sensors, our purpose is to contribute for mitigating one of the main reasons for incidents involving firefighters: the exposure to dangerous concentrations of air pollutants [Miranda et al., 2012]. The main goal of this research is the development of an integrated hardware and software solution that allows online monitoring of vital and environmental parameters that influence the firefighter's health and safety.

\section{System Description}

To achieve the referred goal, two technological paradigms were merged: wearable electronics development and mobile programming, as it is depicted in Figure 2.

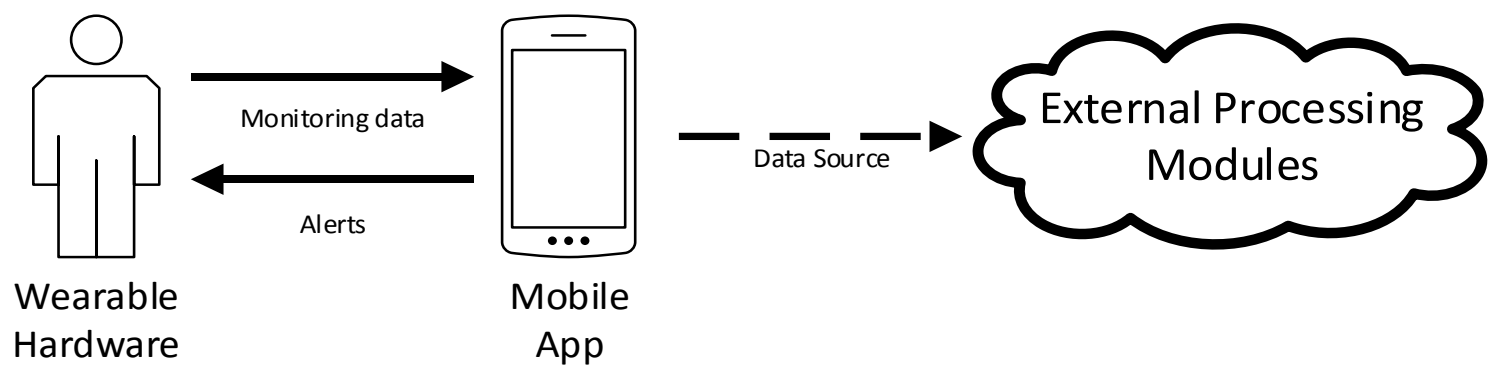

Figure 2. System interaction. 
The wearable hardware consists on a sensored helmet unit (Figure 3) to be used by the firefighter. This device allows the measurement of elevation, air temperature, atmospheric pressure, as also the personal exposure to carbon monoxide $(\mathrm{CO})$ and nitrogen dioxide $\left(\mathrm{NO}_{2}\right)$. These specific air pollutants are known to cause short term effects (e.g. headache, dizziness, nausea, dyspnea, loss of consciousness) [Treitman et al., 1980; Morrow, 1984; Sandstrom et al., 1990; Prockop et al., 2007] that can put a firefighter's life in immediate danger. In order to allow online processing of these variables, the hardware module transmits the information over a Bluetooth network that can be used by smartphones to receive and process the information.

The mobile application uses the information gathered to determine if the firefighter is at an acceptable level of exposure/danger and triggers an alarm, if necessary. Another potential feature of the mobile App is to add some information (e.g. GPS, fall detectors) to the hardware stream and relay it to some kind of superior monitoring platform over Wi-Fi networks. This information can then be used by the team leader to monitor his crew.

\subsection{Hardware Modules}

The hardware modules were developed in-house. The development process was based on the requirements identified based on the outcomes from two research projects:

- FUMEXP (PTDC/AMB/66707/2006), with special emphasis on sensors choice for a set of air pollutants of interest and corresponding typical ranges;

- VitalResponder (CMU/PT/CPS/0046/2008), due to the usability concerns and the technological possibilities already assessed.

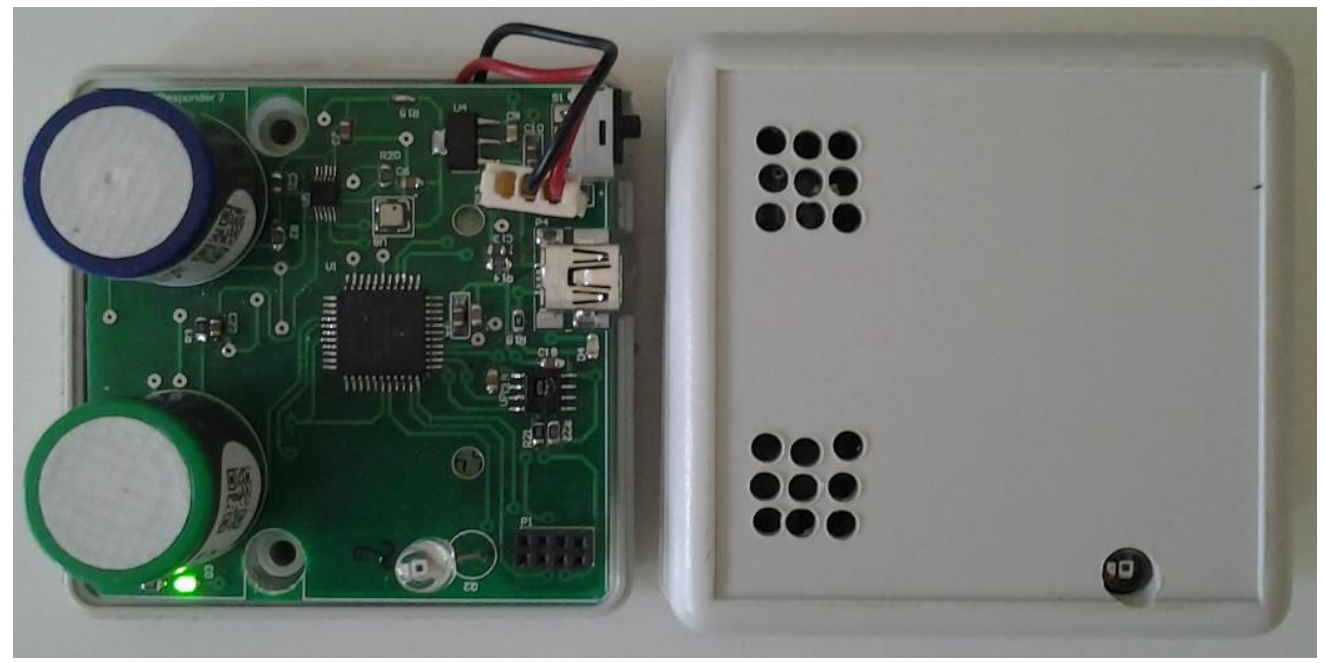

Figure 3. Helmet module prototype: hardware picture (on the left) and its integration on suitable box (on the right).

First of all, a requirement analysis was performed taking into consideration the state of the art on firefighters monitoring systems. It was concluded that the commercial solutions available for the monitoring of human exposure (usually in industrial environments) are not well suited to firefighting operational conditions due to their weight, discomfort and positioning. To mitigate these gaps, and after consulting stakeholders from several fire departments, a hardware device was designed with the objective of being placed on the firefighter's helmet. This approach presents several advantages, but the most representative are:

- ergonomy: with an approximate weight of just $150 \mathrm{~g}$ the device becomes imperceptible to the firefighter that is being monitored;

- proximity to the firefighter airways, allowing accurate measurement of the pollutants inhaled; 
- usability: once the helmet is a part of the mandatory protection equipment, firefighters do not have to take extra concerns about the monitoring device;

- endurance: due to the environmental factors surrounding a wildfire scenario, it's very difficult to keep an electronic device working properly. For this reason, attaching the monitoring device on the helmet improves the hardware's safety and accuracy.

However, attaching a monitoring device on a firefighter helmet is not a trivial process due to its ratification standards (e.g. EN 443 for helmets hull, EN 16471 for wildland firefighting helmets). In order to surpass these constraints, an embedded helmet socket (Figure 4. left) was used to attach the monitoring hardware module (Figure 4. right). Originally, this socket was designed to support attachments as flash lights and fulfils the applied standards.

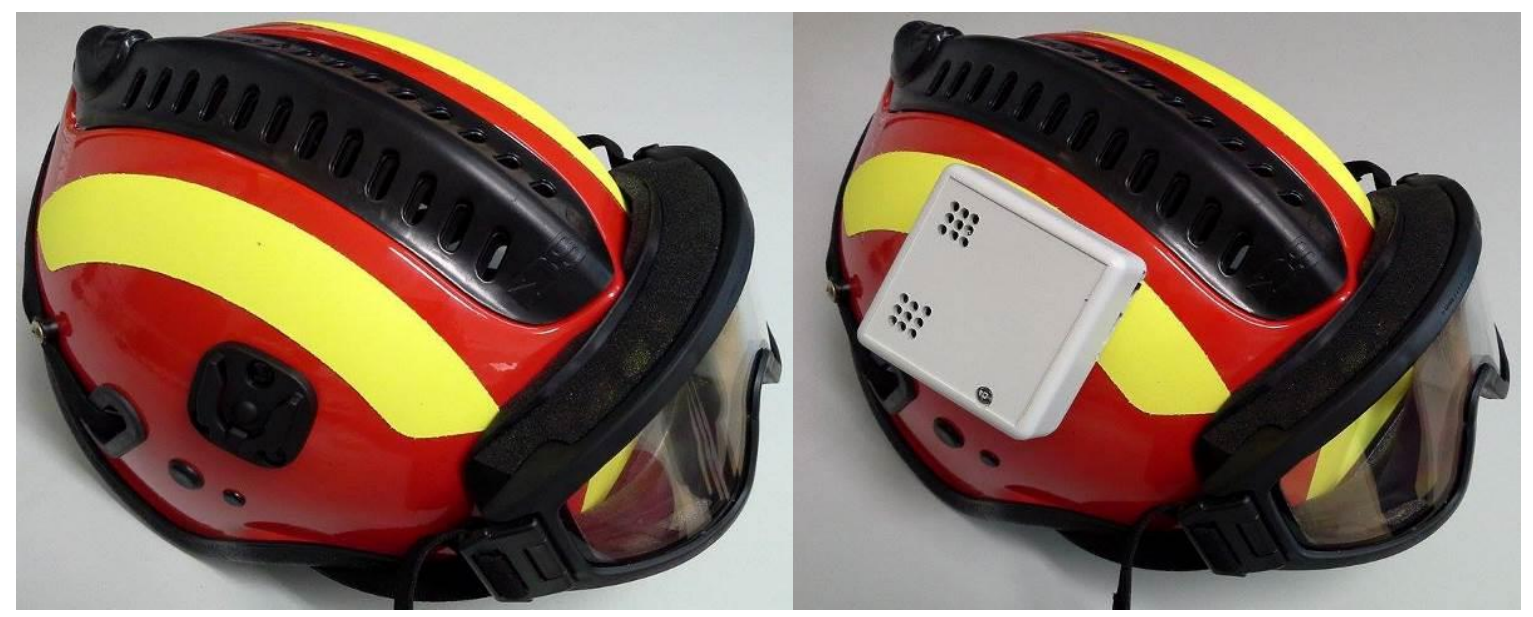

Figure 4. Helmet module prototype integration: original firefighter helmet (on the left) and helmet equipped with monitoring hardware (on the right).

Therefore, in order to build an electronic device small enough to be integrated on a firefighter helmet, we tried to achieve a suitable agreement between the technological possibilities and the most representative environmental variables to measure. Finding support on scientific studies [Ferreira et al., 2011], our helmet unit has sensors to monitor the data depicted on Table 1.

Table 1- Environmental data acquired by the Helmet module

\begin{tabular}{|c|c|}
\hline Variable & Units \\
\hline $\mathrm{NO}_{2}$ & $\mathrm{ppm}$ \\
\hline $\mathrm{CO}$ & $\mathrm{ppm}$ \\
\hline Atmo. Pressure & $\mathrm{hPA}$ \\
\hline Elevation & $\mathrm{m}$ \\
\hline Humidity & $\%$ \\
\hline Temperature & ${ }^{\circ} \mathrm{C}$ \\
\hline Luminosity & $\%$ \\
\hline
\end{tabular}

Technologically, we developed a custom printed circuit board to support all the above mentioned sensors and the remaining necessary components:

- electronic front-ends to bridge all sensors with an Analog-to-Digital conversion

- a microcontroller (MCU) unit to gather and process data from all sensors;

- a bluetooth interface, in order to relay data frames processed by the MCU;

- a battery, providing an autonomy of 24 hours, approximately. 
$\mathrm{CO}$ and $\mathrm{NO}_{2}$ sensors were calibrated using a calibration gas with a known concentration (100 ppm for $\mathrm{CO}$ and $10 \mathrm{ppm}$ for $\mathrm{NO}_{2}$ ).

\subsection{Mobile application}

The mobile application is an evolution of the Android based DroidJacket system [Colunas et al., 2011] with support to receive and process data from the helmet unit described on the above section. It can run in an off-the-shelve Android smartphone supporting bluetooth communication, or it can be integrated on a Wi-Fi network and relay data to any connected device.

To extend the DroidJackets physiological monitoring capabilities with the environmental data relayed by the new Helmet Unit we follow the application's original software architecture, replicating the functionalities implemented for VitalJacket ${ }^{\circ}$. This approach enables us to maintain all application features (e.g. visualization, persistence, danger alarms, network connection) on an already successful evaluation platform.

More specifically, pairing the smartphone with the Helmet Unit, the smartphone receives, displays (Figure 5), stores and relays all environmental data through a Wi-Fi network, if available.

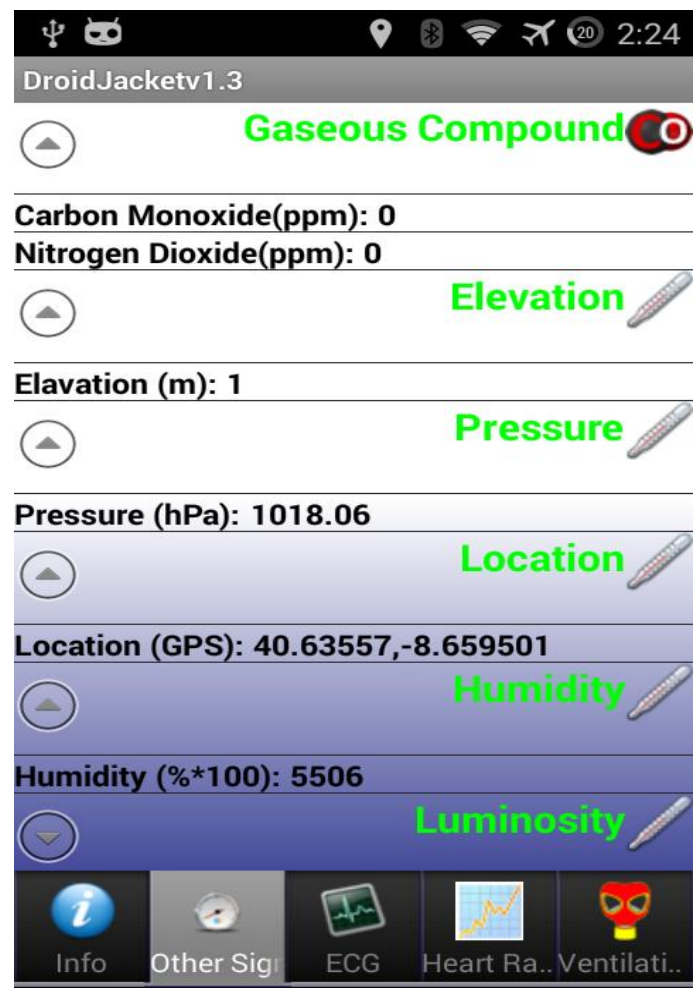

Figure 5 -Improved DroidJacket Version.

Besides the data provided by the Helmet Unit, and other external sensor (e.g. Vital Jacket), the application can use the smartphone's built-in sensors to provide additional information (e.g. GPS, accelerometers, battery).

\subsection{Integrability and Scalability}

The Hardware setup was built with the aim of integrating new sensors on an effortless manner, enhancing integrability and scalability of the overall solution of the Vital Responder project. In this case, we could integrate the previous physiological wearable platform [Coimbra and Cunha, 2012] with the environmental helmet monitoring unit and a GPS. In that sense, the main challenge was related with the sensors size and form-factor 
At the software level, DroidJacket application was used and enhanced. It is an example of scalability, once it has been evolved over several iterations of the project with increasing new features [Marques et al. 2013]. At this point, the DroidJacket Android App can gather, in one smartphone, physiological data (ECG, heart rate and actigraphy, from VitalJacket $\left.{ }^{\circledR}\right)$, environmental data (from Helmet Unit presented above) and GPS location. Furthermore, it enables to add more sensing devices up to the limit of the bluetooth connections ( 7 channels) or the smartphone processing capabilities.

Under development is an ad-hoc data networking technique that will allow the real-time data acquired in the terrain by several of these wearable monitoring equipments and its bridging to a cloud service that will allow numerical forecast that will enable projections of fire progression, smoke levels and critical exposure, aiming to permit safe and efficient positioning of crews.

\subsection{System Evaluation}

The whole system will be tested, on a stand-alone mode, during the summer of 2014. We will deploy the system on two fire departments, at two different operational zones. There will be firefighters equipped with our system and all monitored data will be stored on the smartphones, without connectivity between each other. Additionally, we will ask firefighters to produce mission reports to selectively tag relevant events (arrival to fire scene, approach a fire front, etc.) so that all collected data can be analysed for the intended evaluation.

\section{Conclusions}

Smoke exposure is identified as one of the most important cause of incidents among firefighters. Since the physiological monitoring of firemen has been already addressed, this work signifies one step ahead in this matter, pursuing not only the identification of high risk situations in the terrain, but also contributing to prevent them.

This work proposes a cost-effective solution to monitor firefighters smoke exposure in typical adverse scenarios such as forest fires, allowing the detection and mitigation of hypothetical intoxication incidents. The system is composed of a hardware component easily integrated in standard firefighter protection equipment and a mobile application that can run in any "off-the-shelve" mobile computing device.

Beyond the stand-alone firefighters monitoring perspective, this wearable technological solution opens several opportunities as a data source. In this sense, under development is the integration of the near real-time observations into a Decision Support System (DSS) aiming to provide knowledge-based aid to firefighters at critical decision-making situations, helping with the safe and successful management of fire.

\section{Acknowledgements}

The authors would like to thank the contribution of Oscar Pereira to the work here reported. This work was supported by European Funds through COMPETE and by National Funds through the Portuguese Science Foundation (FCT) within projects PEst-C/MAR/LA0017/2013 and VitalResponder2 (PTDC/EEI-ELC/2760/2012), and the Post-Doc grants of J.H. Amorim (SFRH/BPD/48121/2008) and J. Valente (SFRH/BPD/78933/2011).

\section{References}

Zephyr Technology, Available: http://zephyranywhere.com/training-systems/first-responders/ , (last accessed July 2014)

von Heimburg E. D., et al., Physiological Responses of Firefighters and Performance Predictors During a Simulated Rescue of Hospital Patients, Ergonomics, vol. 49, No. 2, 2006, 111-126 
Teie W. C., et al. , Firefighter's Handbook on Wildland Firefighting: Strategy, Tactics, and Safety, $3^{\text {th }}$ edn., U.S.:Deer Valley Press 2005

Coimbra, M., \& Cunha, J. P. S., 2012. Vital Responder - Wearable Sensing Challenges in Uncontrolled Critical Environments. In F. Martins, L. Lopes \& H. Paulino (Eds.), Sensor Systems and Software (Vol. 102, pp. 45-62): Springer Berlin Heidelberg.

Colunas M. M. F., Fernandes J.M.A., Oliveira I.C., Cunha J.P.S., 2011. Droid Jacket: a mobile monitoring system for a team, In Proc. of: 7th International Wireless Communications and Mobile Computing Conference, IWCMC 2011, 2157-2161.

Cunha J.P.S., Cunha B., Pereira A.S., Xavier W., Ferreira N., Meireles L., 2010. Vital Jacket: A wearable wireless vital signs monitor for patients' mobility in Cardiology and Sports. 4th International ICST Conference on Pervasive Computing Technologies for Healthcare 2010 (ACM, IEEE and IMIA sponsored). Munich, Germany.

Cunha, J.P.S., 2012. pHealth and Wearable Technologies: a permanent challenge, in Studies in Health Technology and Informatics, B. Blobel, P. Pharow, and F. Sousa, Editors. 2012, IOS Press: Amsterdam. p. 185-195.

Miranda A.I., Martins V., Cascão P., Amorim J.H., Valente J., Borrego C., Ferreira A.J., Cordeiro C.R., Viegas D.X., Ottmar R., 2012. Wildland smoke exposure values and exhaled breath indicators on firefighters. Journal of Toxicology and Environmental Health - Part A: Current Issues 75 (1315), 831-843.

Treitman RD, Burgess WA, Gold A. Air contaminants encountered by firefighters. Am Ind Hyg Assoc J 1980; 41:796-802.

Morrow PE. Toxicological data on NOx: an overview. J Toxicol Environ Health 1984; 13: 205-227.

Sandstrom T, Andersson MC, Kolmodin-Headman B, Stjernberg N, Angstrom T. Bronchoalveolar mastotytosis and lymphocytosis after nitrogen dioxide exposure in man: a time kinetic study. Eur Respir J 1990; 3:138-143.

Prockop LD, Chichkova RI, 2007. Carbon monoxide intoxication: an updated review. Journal of the Neurological Sciences, Vol. 262, 122-130.

Ferreira A.J., Cordeiro R.C., Ferreira P., Miranda A.I., Martins V. Viegas D.X., 2011. Firefighter occupational exposures in forest fire settings - Three years of the FUMEXP project, European Respiratory Journal, Vol. 38, p4169.

Marques F., Azevedo P., Cunha J.P.S., Cunha M.B., Brás S., Fernandes J.M., 2013. FIREMAN: FIRefighter team brEathing Management system using ANdroid. In Proc. Of: 17 th International Symposium on Wearable Computers,ISWC 2013, 133-134 